JAMP: Jurnal Adminitrasi dan Manajemen Pendidikan

Volume 3 Nomor 4 Desember 2020, Hal : 332-341

Tersedia Online di http://journal2.um.ac.id/index.php/jamp/

ISSN 2615-8574 (online)

JAINP

JURNAL ADMINISTRASI DAN MANAJEMEN PENDIDIKAN

\title{
MANAJEMEN PEMBIAYAAN PENDIDIKAN DI SMA NEGERI PASCADESENTRALISASI PENDIDIKAN
}

\author{
Noor Fazariah Handayani \\ Nadya Huda \\ Universitas Achmad Yani Banjarmasin, FKIP - .Jalan A.Yani Km 5,5, Banjarmasin \\ E-mail: noorfazariah@uay.ac.id. 082351645140
}

\begin{abstract}
The aim of this research were to: (1) know the implementation of education financing management, (2) evaluate the implementation of education financing management, and (3) determine the role of the education council in education financing management in Banjarmasin City State Senior High School after education decentralization. This research applied an evaluative approach by CIPP model using an observation, documentation questionnaire, and interview. The population of this research were SMAN 1, 2, 3, 4, and 5 Banjarmasin. The samples in this study were teachers, educational staff, principals and education boards. The results showed: (1) Implementation of Education Financing Management in Banjarmasin City State Senior High School after education decentralization with an evaluative approach using the CIPP Model shows that the highest score is in the process variable, namely 5053 points and the lowest score in the context variable of 4667 points; (2) Evaluation of the implementation of education financing management in SMAN Banjarmasin on the education budget implementation variable, education fund budget allocation, education financial administration, education financial accountability, and education financial supervision is effective / good, while the education budget preparation system variable runs Effective enough. In general, education financing management runs Effectively / Well with a value of 86.12\%; (3) The Provincial Education Council has played a role and contributed to the determination of policies for implementing education financing management but it is not yet optimal, so that the community is less aware of its presence.
\end{abstract}

Keywords: Management; Financing; Education; Postdecentralization

Abstrak: Tujuan penelitian ini untuk : (1) mengetahui pelaksanaan manajemen pembiayaan pendidikan di SMA Negeri Kota Banjarmasin pascadesentralisasi pendidikan, (2) mengadakan evaluasi pelaksanaan manajemen pembiayaan pendidikan di SMA Negeri Kota Banjarmasin pascadesentralisasi pendidikan, dan (3) mengetahui peranan dewan pendidikan dalam manajemen pembiayaan pendidikan di SMA Negeri Kota Banjarmasin pascadesentralisasi pendidikan. Penelitian ini menggunakan pendekatan evaluatif dengan model CIPP menggunakan observasi, dokumentasi, angket, dan wawancara. Populasi di penelitian ini adalah Sekolah Menengah Atas Negeri 1, 2, 3, 4, dan 5 Banjarmasin. Sampel di penelitian ini antara lain kepala sekolah, guru, tenaga kependidikan, serta dewan pendidikan. Penelitian ini memperlihatkan hasil: (1) Pelaksanaan Manajemen Pembiayaan Pendidikan di SMA Negeri Kota Banjarmasin pascadesentralisasi pendidikan dengan pendekatan evaluatif menggunakan Model CIPP menunjukkan bahwa nilai tertinggi terdapat pada variabel proses yaitu 5053 poin dan nilai terendah pada variabel konteks sebesar 4667 poin; (2) Evaluasi pelaksanaan Manajemen pembiayaan pendidikan di SMA Negeri Kota Banjarmasin pada variabel pelaksanaan anggaran pendidikan, pengalokasian anggaran dana pendidikan, penatausahaan keuangan pendidikan, pertanggungjawaban keuangan pendidikan, dan pengawasan keuangan pendidikan berjalan dengan Efektif/Baik, sedangkan pada variabel sistem penyusunan anggaran pendidikan berjalan Cukup Efektif. Secara umum Manajemen 
pembiayaan pendidikan berjalan secara Efektif/Baik dengan nilai sebesar 86,12\%; (3) Dewan Pendidikan Provinsi telah berperan dan ikut berkontribusi dalam penentuan kebijakan pelaksanaan manajemen pembiayaan pendidikan namun belum optimal, sehingga masyarakat kurang menyadari kehadirannya

Kata kunci: Manajemen; Pembiayaan; Pendidikan; Pascadesentralisasi

Pada dunia pendidikan baik sekolah umum/formal maupun sekolah non-formal memerlukan pengelolaan pembiayaan dan pendanaan pendidikan yang baik agar proses pembelajaran dapat tercapai dan memiliki mutu lulusan yang berkualitas. Pembiayaan dan pendanaan pendidikan yang dimaksud terdapat dalam Peraturan Pemerintah Republik Indonesia No.48 Tahun 2008 mengenai Pembiayaan dana Pendidikan yaitu pendanaan pendidikan menjadi tanggungjawab semua pihak yaitu pemerintah pusat, pemerintah daerah, bahkan masyarakat. Berdasarkan hal yang tersebut dalam peraturan,maka proses kependidikan memerlukan sumber pembiayaan/ pendanaan yang mencukupi dan memadai dari pemerintah pusat, pemerintah daerah, bahkan juga masyarakat. Ketentuan anggaran pendidikan untuk sekolah formal terdapat dalam UU No.20/ 2003 mengenai Sisdiknas pasal 49 tentang Pengalokasian Dana Pendidikan yang menyebutkan bahwa biaya pendidikan kedinasan dialokasikan minimal $20 \%$ dari APBN setiap tahunnya dalam sepuluh tahun belakangan untuk memperbaiki pendidikan di dalam negeri untuk sektor pendidikan selain gaji pendidik dan minimal 20\% dari APBD (Anggaran Pendapatan dan Belanja Daerah).

Dalam Undang-undang No. 32/2004 tentang Pemerintah Daerah menyatakan bahwa daerah memiliki kewenangan nyata yang luas dan bertanggung jawab untuk mengelola sendiri segala hal yang telah didesentralisasikan salah satunya bidang pendidikan karena perlu perencanaan program kependidikan yang selaras dengan kepentingan daerah, pengaturan keuangan daerah baik sumber maupun pengalokasiannya agar bidang pendidikan dapat diselenggarakan sesuai tujuan yang telah ditentukan. Pada Undang-undang No.20 Tahun 2003, Sistem Pendidikan Nasional (Sisdiknas) peran dan fungsi kedua lembaga tersebut dijelaskan. Dewan Pendidikan memiliki peranan selaku pemberi pertimbangan, pendukung, pengontrol, dan mediator. Adapun fungsinya antara lain Memotivasi agar masyarakat berhadir dengan komitmen tanggung jawab terhadap mutu dan kualitas pengelolaan pendidikan. Sedangkan peran Komite Sekolah setara dengan peran Dewan Pendidikan, tetapi Komite Sekolah berada pada tingkat pendidikan dasar maupun tingkat pendidikan menengah.

Program Kerja Komite Sekolah yang dirancang setiap tahun ajaran merupakan representasi dari seluruh kekuatan yang dimiliki Komite Sekolah baik kekuatan sumber daya, tenaga, maupun program kerja seperti menggali dukungan dana untuk kebutuhan penyelenggaraan sekolah agar terlaksana kegiatan sekolah secara efektif dan berkelanjutan sehingga upaya peningkatan pendidikan baik proses maupun hasil dapat memenuhi standar pembiayaan sekolah yang memadai. Komite Sekolah memegang peranan berdasarkan konsep Manajemen Berbasis Sekolah(MBS) sebagai jawaban pascadesentralisasi di bidang pendidikan dan telah diatur dalam Undang-Undang No.20/2003 tentang Sisdiknas Pasal 51 ayat (1) yang berbunyi, "Pengelolaan satuan pendidikan anak usia dini, pendidikan dasar, dan pendidikan menengah dilaksanakan berdasarkan standar pelayanan minimal dengan prinsip manajemen berbasis sekolah"(Usman, 2014).

Implementasi Manajemen Berbasis Sekolah (MBS) pascadesentralisasi pendidikan, dapat memberikan implikasi antara lain memberikan kewenangan kepada sekolah dalam menetukan sendiri jumlah dan jenis alokasi biaya pendidikan sesuai dengan kebutuhan dan karakteristik sekolah sebagaimana saran dari pemerintah dalam Peraturan Pemerintah Nomor 19 Tahun 2005 tentang Standar Nasional Pendidikan. Adanya kewenangan sekolah dalam menentukan jumlah dan jenis alokasi biaya tersebut, merupakan salah satu dampak langsung dari adanya reformasi sistem keuangan dalam bidang pendidikan. Dalam penggunaan konsep Manajemen Berbasis Sekolah (MBS) ada beberapa hal yang perlu dikelolah, salah satunya adalah manajemen pembiayaan pendidikan.

Penelitian yang dilakukan Mawardi dan Fadliah (2020) tentang evaluasi pelaksanaan manajemen berbasis sekolah di SDN Kebun Bunga 6 Banjarmasin Timur menggunakan model CIPP menunjukkan 
bahwa pelaksanaan MBS pada bidang manajemen kurikulum dan pembelajaran, peserta didik, hubungan sekolah dan masyarakat, budaya dan lingkungan sekolah berjalan dengan Efektif/Baik, sedangkan bidang manajemen pendidik dan tenaga kependidikan, pembiayaan, serta manajemen sarana dan prasarana berjalan Cukup Efektif. Secara umum manajemen MBS berjalan dengan Efektif/Baik dengan skor sebesar 1277 point dengan nilai 76,01\%.

Penelitian Chairuwidha (2019) tentang pengaruh manajemen pembiayaan pendidikan terhadap mutu lulusan kelas IX di SMP IT Ar Ridwan Bekasi, menunjukkan bahwa $\mathrm{T}_{\text {hitung }}>\mathrm{T}_{\text {tabel }}$, yaitu 4,424 >2,120, yang artinya $\mathrm{H}_{0}$ ditolak. Hasil uji regresi linear sederhana memperlihatkan bahwa nilai konstanta (a) sebesar 35,060, yang artinya mutu lulusan SMP IT Ar Ridwan Bekasi adalah sebesar 35. Nilai koefisien regresi variable harga (b) yaitu 0,553 , angka ini mengandung arti bahwa setiap penambahan $1 \%$ tingkat Manajemen Pembiayaan Pendidikan maka Mutu Lulusan akan meningkat sebesar 0,553. Serta nilai RSquare sebesar 0,550 yang artinya, sebesar 55\% mutu lulusan SMP IT Ar Ridwan Bekasi dipengaruhi oleh manajemen pembiayaannya, dan sebesar $45 \%$ dipengaruhi oleh faktor lain.

Penelitian Herawati, dkk (2020) tentang Kinerja Dewan Pendidikan dalam meningkatkan mutu pendidikan menyatakan bahwa Masyarakat umumnya tidak memahami eksistensi Dewan Pendidikan, peran serta masyarakat dalam pendidikan sebagai Komite Sekolah belum tersentuh secara optimal, dan tidak adanya aturan mengenai alokasi anggaran bagi pelaksanaan kegiatan mengakibatkan Dewan Pendidikan tidak dapat berkontribusi secara optimal.

Kota Banjarmasin sebagai salah satu daerah otonomi baru, memiliki wadah sebagai penyalur aspirasi stakeholders yaitu Dewan Pendidikan dan Komite Sekolah. Berdasar observasi pendahuluan, implementasi kedua lembaga tersebut belum sepenuhnya berjalan dengan baik, disebabkan masih kurangnya sosialisasi sehingga anggaran biaya pendidikan belum sepenuhnya dimanfaatkan secara optimal, salah satunya karena kurang tertibnya pelaksanaan manajemen pembiayaan pendidikan pascadesentralisasi, terbatasnya sarana dan prasarana pendukung, dana operasional yang terbatas, dukungan pemerintah Kota Banjarmasin masih relatif kecil baik berupa kebijakan maupun dana, serta kinerja pelaksanaan manajemen pembiayaan pendidikan menyebabkan lambannya upaya peningkatan mutu pendidikan di Kota Banjarmasin. Kurang lengkapnya data pelaksanaan manajemen pembiayaan pendidikan ini dapat berpengaruh pada perencanaan program pendidikan dan pelaksanaannya pada masing-masing SMA Negeri di Kota Banjarmasin.

Berdasarkan latar belakang tersebut, penelitian ini bertujuan untuk (1) Mengetahui Pelaksanaan Manajemen Pembiayaan Pendidikan di SMA Negeri di Kota Banjarmasin, (2) Mengadakan evaluasi pelaksanaan Manajemen Pembiayaan Pendidikan di SMA Negeri di Kota Banjarmasin dengn Model CIPP, dan (3) Mengetahui peranan Dewan Pendidikan Kota Banjarmasin dalam pembiayaan pendidikan SMA Negeri Kota Banjarmasin pasca desentralisasi pendidikan. Mawardi dan Fadliah (2020) telah meneliti Pelaksanaan semua komponen MBS, maka penelitian ini fokus hanya pada salah satu komponen MBS yaitu manajemen pembiayaan pendidikan sebagai kebaharuan. Urgensi Penelitian antara lain untuk memberikan informasi pelaksanaan manajemen pembiayaan pendidikan di SMA Negeri di Kota Banjarmasin, serta dapat memberikan informasi lebih lanjut bagi masyarakat tentang sekolah yang bersangkutan dalam hal pelaksanaan manajemen pembiayaan pendidikan di SMA Negeri di Kota Banjarmasin.

\section{METODE}

Penelitian ini menggunakan pendekatan evaluatif. Menurut Kidder (Riduwan, 2010:50) penelitian evaluasi diutarakan sebagai penelitian juga sebagai evaluasi. Selaku evaluasi, maka ini merupakan bagian dari proses pembuatan dan pengambilan keputusan, yaitu untuk membandingkan suatu kegiatan, kejadian, produk dengan standar dan program yang telah diberlakukan. Evaluasi sebagai penelitian memiliki fungsi untuk menjelaskan kejadian kegiatan. Ada dua penelitian evaluasi yaitu: Penelitian evaluasi formatif yang mengutamakan pada proses dan penelitian evaluasi sumatif yang memfokuskan pada produk. 
Menurut Mawardi dan Fadliah (2020) terdapat empat komponen pelaksanaan evaluasi, terdiri dari, Context yaitu context evaluation (evaluasi terhadap konteks), Input yaitu input evaluation (evaluasi terhadap masukan), Process yaitu process evaluation: evaluasi terhadap proses, dan Product yaitu product evaluation: (evaluasi terhadap hasil atau produk), yang disingkat menjadi CIPP sebagai Model penelitian. Berdasarkan model CIPP, maka penelitian ini menetapkan aspek kajian yaitu Konteks perencanaan anggaran dan pembagian tugas tiap bagian, Input dalam anggaran pendidikan berupa sumber pendapatan, identifikasi kebutuhan, persetujuan sasaran, dan pembuatan program yang relevan; Proses pengalokasian dana mencakup implementasi manajemen pembiayaan pendidikan di sekolah, terjadinya pengawasan dan penyesuaian dengan tetap melaksanakan program yang telah ditetapkan sebelumnya; dan Produk atau hasil keluaran yang mencakup RAPBS, laporan pertanggungjawaban yang diterbitkan, serta evaluasi pencapaian tujuan.

Penelitian ini menggunakan pendekatan evaluatif formatif, yang lebih menekankan pada proses pelaksanaan manajemen pembiayaan pendidikan di Sekolah Menengah Atas Negeri di Kota Banjarmasin. Objek penelitian ini adalah "Manajemen Pembiayaan Pendidikan di SMA Negeri di Kota Banjarmasin, meliputi: sistem penyusunan anggaran, pelaksanaan anggaran, pengalokasian anggaran, penatausahaan keuangan, pertanggungjawaban keuangan, dan pengawasan keuangan". Subjek penelitian ini adalah SMA Negeri 1 Banjarmasin, SMA Negeri 2 Banjarmasin, SMA Negeri 3 Banjarmasin, SMA Negeri 4 Banjarmasin, dan SMA Negeri 5 Banjarmasin di Provinsi Kalimantan Selatan. Pengumpulan data penelitian dengan menggunakan teknik observasi, angket, dan wawancara terhadap responden yang sudah termasuk dalam daftar responden.

Adapun parameter efektivitas pelaksanaan manajemen pembiayaan pendidikan adalah (1) ketepatan penyusunan program yang ditetapkan sesuai kebutuhan, (2) adanya pembagian tugas, wewenang, dan tanggungjawab secara jelas untuk setiap unit di sekolah, (3) mampu mengatasi perubahan yang terjadi tanpa perlu perubahan yang besar, dan (4) menghasilkan produk berupa laporan ditinjau dari hasil penerimaan, waktu, biaya, untuk menyelenggarakan program dengan ketercapaian tujuan yang telah ditetapkan (Fatimah, dkk: 2008).

Hasil pengolahan data dianalisa menggunakan model evaluasi CIPP yang diharapkan dapat memberikan gambaran terhadap pelaksanaan manajemen pembiayaan pendidikan di SMA Negeri Kota Banjarmasin. Untuk mengetahui skor pelaksanaan, digunakan pendekatan persentase Arikunto (2014:54) sesuai interpretasi kriteria Riduwan (2014: 29) dengan Kategori nilai Efektif/Baik sebesar 76-100\%, kategori nilai Cukup Efektif sebesar 51-75\%, kategori nilai Kurang Efektif sebesar 26-50\%, dan kategori nilai Tidak Efektif $<25 \%$ sebagai berikut:

$$
\text { Nilai Skor }=\frac{\text { Skor Jawaban }}{\text { Skor Maksimal }} \times 100 \%
$$

\section{HASIL}

Penelitian yang telah dilaksanakan di SMA Negeri Kota Banjarmasin mengenai manajemen pembiayaan pendidikan di SMA Negeri Kota Banjarmasin pascadesentralisasi pendidikan dengan menggunakan pendekatan evaluatif model CIPP menunjukkan hasil sebagaimana pada tabel 1. 
Tabel 1. Tabel Rekapitulasi Manajemen Pembiayaan Pendidikan di SMA Negeri Kota Banjarmasin Pascadesentralisasi Pendidikan

\begin{tabular}{|c|c|c|c|c|c|c|c|c|}
\hline \multirow{2}{*}{ No. } & \multirow{2}{*}{ Dekripsi } & \multicolumn{4}{|c|}{ Jawaban Responden } & \multirow{2}{*}{$\begin{array}{c}\text { Jumlah } \\
\text { Nilai } \\
\end{array}$} & \multirow{2}{*}{$\begin{array}{c}\text { Nilai } \\
\% \\
\end{array}$} & \multirow{2}{*}{$\begin{array}{c}\text { Hasil/ } \\
\text { Kriteria }\end{array}$} \\
\hline & & $\mathrm{C}$ & $\mathbf{I}$ & $\mathbf{P}$ & $\mathbf{P}$ & & & \\
\hline I. & Sistem Penyusunan Anggaran & 449 & 506 & 591 & 550 & 2096 & 74.43 & Cukup Efektif \\
\hline II. & Pelaksanaan Anggaran & 598 & 537 & 581 & 596 & 2312 & 82.10 & Efektif/Baik \\
\hline III. & Pengalokasian Anggaran & 1180 & 1122 & 1233 & 1179 & 4714 & 83.70 & Efektif/Baik \\
\hline IV. & Penatausahaan Anggaran & 1218 & 1280 & 1308 & 1331 & 5137 & 91.21 & Efektif/Baik \\
\hline V. & Pertanggungjawaban Keuangan & 621 & 679 & 673 & 658 & 2631 & 93.43 & Efektif/Baik \\
\hline \multirow[t]{2}{*}{ VI. } & Pengawasan Anggaran & 601 & 631 & 667 & 612 & 2511 & 89.17 & Efektif/Baik \\
\hline & Grand Total & 4667 & 4755 & 5053 & 4926 & 19401 & 86.12 & Efektif/Baik \\
\hline
\end{tabular}

Keterangan:

C : Context Evaluation (evaluasi terhadap konteks)

I : Input Evaluation (evaluasi terhadap masukan)

P : Process Evaluation (evaluasi terhadap proses)

P : Product Evaluation (evaluasi terhadap hasil)

Bila pelaksanaan Manajemen Pembiayaan Pendidikan ditinjau dari variabel sistem penyusunan anggaran, maka nilai pada konteks sebesar 449 poin, nilai input sebesar 506 poin, nilai proses sebesar 591 poin, dan nilai produk sebesar 550 poin. Nilai terendah sebesar 449 poin pada variabel konteks. Nilai tertinggi pada variabel proses sebesar 591 poin.

Bila pelaksanaan Manajemen Pembiayaan Pendidikan ditinjau dari variabel pelaksanaan anggaran, maka nilai pada konteks sebesar 598 poin, nilai input sebesar 537 poin, nilai proses sebesar 581 poin, dan nilai produk sebesar 596 poin. Nilai terendah sebesar 437 poin pada variabel input. Nilai tertinggi pada variabel konteks sebesar 598 poin.

Bila pelaksanaan Manajemen Pembiayaan Pendidikan ditinjau dari variabel pengalokasian anggaran, maka nilai pada konteks sebesar 1180 poin, nilai input sebesar 1122 poin, nilai proses sebesar 1233 poin, dan nilai produk sebesar 1179 poin. Nilai terendah sebesar 1122 poin pada variabel input. Nilai tertinggi pada variabel proses sebesar 1233 poin.

Bila pelaksanaan Manajemen Pembiayaan Pendidikan ditinjau dari variabel penatausahaan anggaran, maka nilai pada konteks sebesar 1218 poin, nilai input sebesar 1280 poin, nilai proses sebesar 1308 poin, dan nilai produk sebesar 1331 poin. Nilai terendah sebesar 1218 poin pada variabel konteks. Nilai tertinggi pada variabel produk sebesar 1331 poin.

Bila pelaksanaan Manajemen Pembiayaan Pendidikan ditinjau dari variabel pertanggungjawaban keuangan, maka nilai pada konteks sebesar 621 poin, nilai input sebesar 679 poin, nilai proses sebesar 673 poin, dan nilai produk sebesar 658 poin. Nilai terendah sebesar 621 poin pada variabel konteks. Nilai tertinggi pada variabel input sebesar 679 poin.

Bila pelaksanaan Manajemen Pembiayaan Pendidikan ditinjau dari variabel pengawasan anggaran, maka nilai pada konteks sebesar 601 poin, nilai input sebesar 631 poin, nilai proses sebesar 667 poin, dan nilai produk sebesar 612 poin. Nilai terendah sebesar 601 poin pada variabel konteks. Nilai tertinggi pada variabel proses sebesar 567 poin.

Pelaksanaan Manajemen Pembiayaan Pendidikan di SMA Negeri Kota Banjarmasin pascadesentralisasi pendidikan dengan pendekatan evaluatif menggunakan Model CIPP menunjukkan bahwa nilai tertinggi terdapat pada variabel proses yaitu 5053 poin dan nilai terendah pada variabel konteks sebesar 4667 poin. 


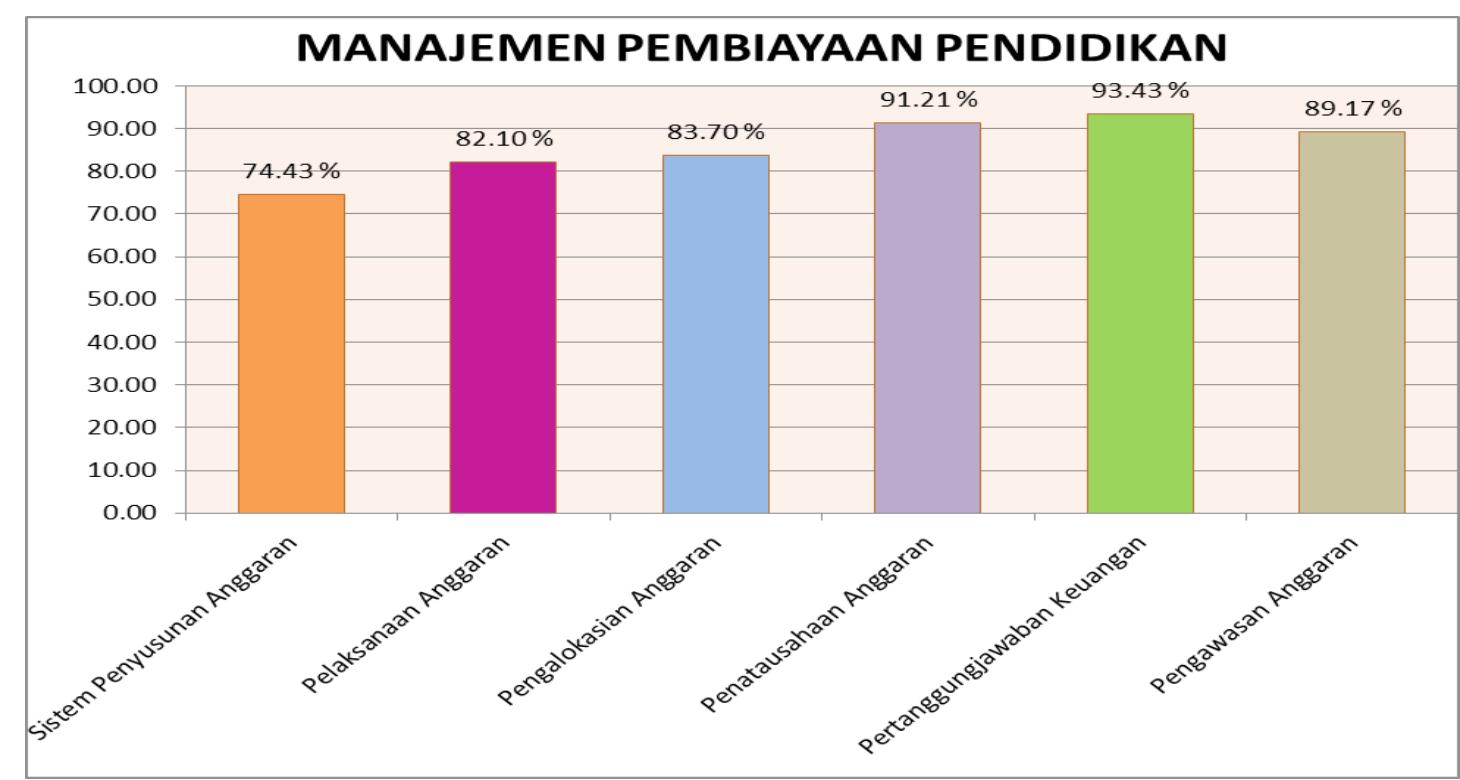

Gambar 1. Rekapitulasi Hasil Capaian Evaluasi Pelaksanaan Manajemen Pembiayaan Pendidikan di SMA Negeri Kota Banjarmasin dengan Model CIPP berdasarkan variabel

Gambar 1 memperlihatkan hasil evaluasi berdasarkan variabel pelaksanaan manajemen pembiayaan pendidikan pascadesentralisasi pendidikan adalah Pelaksanaan sistem penyusunan anggaran mempunyai capaian nilai 74,43\% yang termasuk dalam kategori hasil/kriteria pelaksanaan Cukup Efektif. Evaluasi Pelaksanaan anggaran mempunyai capaian nilai $82,10 \%$ yang termasuk dalam kategori hasil/kriteria pelaksanaan Efektif/Baik. Evaluasi Pelaksanaan pengalokasian anggaran mempunyai capaian nilai 83,70\% yang termasuk dalam kategori hasil/kriteria pelaksanaan Efektif/Baik. Evaluasi Pelaksanaan penatausahaan keuangan mempunyai capaian nilai 91,21\% yang termasuk dalam kategori hasil/kriteria pelaksanaan Efektif/Baik. Evaluasi Pelaksanaan anggaran mempunyai capaian nilai 93,43\% yang termasuk dalam kategori hasil/kriteria pelaksanaan Efektif/Baik. Evaluasi Pelaksanaan pengawasan anggaran mempunyai capaian nilai $89,17 \%$ yang termasuk dalam kategori hasil/kriteria pelaksanaan Efektif/Baik. Secara umum Evaluasi proses pelaksanaan manajemen pembiayaan pendidikan di SMA Negeri Kota Banjarmasin adalah 19401 point dan 86,12\% dengan hasil/Kriteria Efektif/Baik.

\section{PEMBAHASAN}

\section{Manajemen Pembiayaan Pendidikan diSMANegeri Kota Banjarmasin Pascadesentralisasi Pendidikan}

Manajemen pembiayaan pendidikan memiliki arti sama dengan pengelolaan dana pendidikan, yang terdiri dari sistem penganggaran pendidikan, pelaksanaan anggaran pendidikan, menentukan alokasi anggaran, penatausahaan keuangan pendidikan, pertanggungjawaban keuangan pendidikan, dan pengawasan anggaran (Matin, 2014:55).

Pembiayaan pendidikan merupakan hubungan saling keterkaitan yang didalamnya terdapat komponen satuan pendidikan yang bersifat makro bahkan mikro. Yang memiliki tujuan yaitu pada peningkatan potensi sumber daya manusia yang berkualitas, penyediaan komponen-komponen sumbersumber pembiayaan pendidikan, penetapan sistem dan mekanisme pengalokasian dana, pengefektifan dan pengefisiensian penggunaan dana, akuntabilitas (dapat dipertanggungjawabkan) dari aspek keberhasilan dan mudah terukur pada setiap satuan pendidikan, meminimalis terjadinya permasalahanpermasalahan yang terkait dengan penggunaan pembiayaan pendidikan (Putera, 2013:566). Sementara itu menurut Nanang Fattah (Mulyono, 2016:78), pembiayaan pendidikan merupakan jumlah uang yang diperoleh untuk berbagai macam keperluan pengelolaan proses pendidikan. Pembiayaan pendidikan ialah hal penting yang tidak dapat dipungkiri dalam pengelolaan pendidikan di sekolah. 
Pembiayaan salah satu hal penting penyelenggaraan pendidikan yang harus dikelola dengan baik. Ketidakmampuan dalam mengelola pembiayaan pendidikan akan berdampak buruk pada kegiatan operasional sekolah. Hasil penelitian memperlihatkan pelaksanaan manajemen pembiayaan pendidikan di SMAN Kota Banjarmasin variabel pengalokasian anggaran nilai tertinggi terdapat pada variabel proses sebesar 1233 poin, hal ini menunjukkan bahwa proses alokasi dana sangat penting dan harus jelas skala prioritasnya. Setiap satuan pendidikan memiliki tujuan yang berbeda sehingga alokasi dana harus disesuaikan berdasarkan tujuannya dan semua pihak bersama-sama mempertimbangkan pengalokasian pembiayaan pendidikan secara cermat agar efektif dan efisien. Pada variabel penatausahaan anggaran nilai tertinggi terdapat pada variabel produk sebesar1331 poin yang ditunjukkan adanya kumpulan bukti-bukti penggunaan pembiayaan pendidikan yang wajib dilakukan oleh semua pihak baik itu kepala sekolah, guru maupun tenaga pendidik yang menggunakan dana pendidikan seperti tanda tangan penerima honor, pembelian barang yang harus menggunakan materai dan sebagainya. Secara umum, pelaksanaan manajemen pembiayaan pendidikan SMAN Kota Banjarmasin memperoleh nilai tertinggi pada variabel proses.

Pradesentralisasi pendidikan, sekolah-sekolah sebagai pelaksana pendidikan di daerah tidak memiliki kewenangan untuk mengambil keputusan sendiri sesuai dengan keadaan dan kebutuhannya. Pascadesentralisasi pendidikan, sumber-sumber pembiayaan pendidikan telah menjadi urusan pemerintah daerah, masyarakat di daerah, orang tua siswa/keluarga siswa yang disesuaikan dengan kesanggupan, kepentingan, dan kapasitas masing-masing daerah. Menurut Toifur (2011) dengan adanya otoritas yang besar dalam pengelolaan kegiatan pendidikan, pemerintah daerah pun termotivasi untuk menelusuri berbagai potensi kesanggupan daerah dan menjadikan masyarakat terdorong untuk berpartisipasi membantu pendanaan pembangunan kependidikan di daerahnya. Sebaliknya, partisipasi masyarakat dapat ditingkatkan jika manajemen pendidikan di sekolah di daerah terlaksanakan secara efektif, efisien, transparant, dan akuntabel, serta tanggap terhadap keinginan dan kebutuhan masyarakat. Komitmen pemerintah daerah pascadesentralisasi pendidikan dalam pembiayaan pendidikan dibuktikan melalui anggaran pendidikan dipersiapkan dalam Anggaran Pendapatan Belanja Daerah (APBD) tertuang dalam peraturan daerah Provinsi Kalimantan Selatan Nomor 03 Tahun 2017 tentang Pendidikan sebagai bukti yang paling mudah untuk dilihat masyarakat.

\section{Evaluasi Pelaksanaan Manajemen Pembiayaan Pendidikan di SMA Negeri Kota Banjarmasin dengan Model CIPP}

Pada evaluasi pelaksanaan sistem penyusunan anggaran dengan kategori hasil/kriteria pelaksanaan Cukup Efektif, menunjukkan bahwa hanya administrator dan manajer dalam hal ini hanya kepala sekolah, wakil kepala sekolah dan bendahara, yang lebih mengerti dan memahami serta menguasai sistem penganggaran yang berlaku, sehingga para guru maupun tenaga pendidik kurang mengetahuinya. Matin (2014: 55-56) menyatakan bahwa untuk dapat menyusun anggaran pendidikan yang tepat, pada administrator dan manajer pendidikan harus memahami dan menguasai sistem penganggaran yang berlaku di suatu negara, terdapat enam sistem penganggaran pendidikan yang dikenal dan dianut oleh suatu negara, yaitu: Line Item Budgeting (LIB), Capital Budgeting (CAB), Performance Budgeting (PEB), Program Budgeting (PROB), Planning Programming and Budgeting System (PPBS), dan Zero BaseBudgeting (ZBB).

Evaluasi Pelaksanaan anggaran memperlihatkan kategori hasil/kriteria pelaksanaan yang Efektif/ Baik, dimana berdasarkan hakikatnya pelaksanaan anggaran adalah kegiatan penyesuaian anggaran sesuai peraturan perundang-undangan yang telah diberlakukan, baik berupa peraturan perundangundangan anggaran rutin maupun anggaran pembangunan. Dalam pelaksanaan anggaran diperlukan penentuan besar anggaran dan analisa biaya pendidikan di masing-masing sekolah.

Pada evaluasi pelaksanaan pengalokasian anggaran menunjukkan kategori hasil/kriteria pelaksanaan Efektif/Baik, karena dalam pengalokasian anggaran terdapat beberapa kegiatan seperti (1) inventarisasi sumber dana pendidikan yaitu: Dana Bos Reguler dari Pemerintah Pusat dimulai sejak tahun 2005 
hingga sekarang, Dana Bosda dari Pemerintah Daerah Provinsi Kalimantan Selatan dimulai sejak tahun 2017, dan sumbangan dari masyarakat/para orang tua siswa, berdasarkan hasil observasi semenjak tahun 2017 di SMAN Kota Banjarmasin tidak diperkenankan ada iuran komite namun berupa sumbangan dengan sifat yang tidak mengikat berdasarkan Perda Provinsi Kalimantan Nomor 3 Tahun 2017 tentang Pendidikan. (2) alokasi anggaran yang berupa pengalokasian dana atas dasar siswa, guru, banyaknya ruang belajar, bobot tujuan pendidikan, peningkatan angka partisipasi, dan atas dasar pengamatan terhadap rumus alokasi keuangan. (3) penentuan skala prioritas menggunakan pola pedoman dengan melaksanakan lima langkah kegiatan: (a) memeriksa, merumuskan, dan menjabarkan permasalahan; (b) menyusun kriteria untuk melakukan seleksi prioritas; (c) mengidentifikasi alternatif kebijaksanaan untuk mencapai tujuan; (d) mengevaluasi alternatif kebijaksanaan; dan (e) menyusun prioritas kebijaksanaan.

Pada evaluasi pelaksanaan penatausahaan keuangan dalam kategori hasil/kriteria pelaksanaan Efektif/Baik, menunjukkan pelaksanaan kegiatan penatausahaan ini adalah kewajiban pendataan pelaporan transaksi keuangan dalam bidang pendidikan harus tercatat sesuai kronologis ssecara sistematis berdasar periode tertentu yang telah ditetapkan, dimana tiap catatan harus dilengkapi dengan dokumen keuangan. Dan pembukuan pelaksanaan anggaran pendidikan pembukuan, dimana dilakukan pencatatan, penggolongan, dan pengikhtisaran transaksi-transaksi keuangan sebagai teknis akuntansi, yang tidak hanya melakukan pembukuan, tetapi juga melakukan pemeriksaan laporan, penyusunan keuangan, penafsiran laporan keuangan, dan lain sebagainya.

Evaluasi Pelaksanaan Pertanggung Jawaban Keuangan dalam kategori hasil/kriteria pelaksanaan Efektif/Baik, dimana salah satu aktivitasnya adalah pembuatan laporan keuangan dari pengelolaan anggaran keuangan bidang pendidikan yang tersusun rapi setelah semua bukti pengeluaran diuji keabsahan dan kebenarannya berdasar ketentuan peraturan perundang-undangan yang telah berlaku,untuk disampaikan ke instansi terkait. Variabel ini menyangkut dengan pencairan dana selanjutnya dari pemerintah pusat maupun pemerintah daerah, jika laporan pertanggung-jawaban terlambat dilaporkan maka pencairan dana BOS Reguler maupun BOSDA selanjutnya pun akan terlambat.

Evaluasi Pelaksanaan pengawasan anggaran memperlihatkan kategori hasil/kriteria pelaksanaan Efektif/Baik, yang terdiri dari evaluasi penggunaan anggaran pendidikan, dan pelaporan penggunaan anggaran pendidikan. Evaluasi penggunaan anggaran pendidikan adalah aktivitas melakukan pengukuran untuk menilai perkembangan atau tingkat keberhasilan pelaksanaan rencana dan program berdasarkan kriteria tertentu. Pelaporan penggunaan anggaran pendidikan adalah bagian dari sistem pengawasan yang berkenaan dengan hasil-hasil pelaksanaan rencana dan program pendidikan, masalah dan hambatan yang dihadapi, dan alternatif-alternatif yang digunakan untuk mengatasi permasalahan tersebut.

\section{Peranan Dewan Pendidikan dalam Manajemen Pembiayaan Pendidikan di SMA Negeri Kota Banjarmasin Pascadesentralisasi Pendidikan}

Menteri Pendidikan mendeklarasikan dalam Keputusan Menteri Nomor 044/U/2002 bahwa Dewan Pendidikan memegang peranan antara lain sebagai: (1) Badan penasehat (advisory agency) dalam penetapan realisasi kebijakan pendidikan (2) Penunjang (supporting agency), baik yang berwujud gagasan, financial, bahkan tenaga dalam pengurusan pendidikan. (3) Pengontrol (controlling agency) dalam hal akuntabilitas keterbukaan pengelolaan pendidikan. (4) Mediator antara masyarakat dengan pihak legislatif/DPRD dan pihak eksekutif yaitu pemerintah. Dewan pendidikan Provinsi Kalimantan Selatan beranggotakan akademisi dari berbagai perguruan tinggi di Kalimantan Selatan.

Dewan Pendidikan dalam Keputusan Menteri Pendidikan Nasional Nomor 044/U/2002 juga memiliki fungsi antara lain: (1) Memotivasi agar masyarakat berhadir dengan komitmen tanggung jawab terhadap mutu dan kualitas pendidikan (2) bekerjasama dengan masyarakat baik secara perorangan 
maupun organisasi, pemerintah pusat juga daerah berkenaan pengurusan pendidikan lebih bermutu (3) Menghimpun berbagai ide, aspirasi, tuntutan, serta keperluan pendidikan yang direkomendasikan oleh masyarakat juga menganalisanya (4) Memberi pandangan, masukan, pertimbangan, serta rekomendasi kepada pemerintah daerah berkenan program kebijakan pendidikan; dan berbagai hal yang berhubungan dengan bidang pendidikan (5) Memberikan motivasi kepada orangtua dan masyarakat agar bersedia ikut serta mendukung peningkatan kualitas mutu pendidikan secara merata di seluruh sekolah (6) Melakukan evaluasi dan pengawasan terhadap kebijakan pendidikan, program kependidikan, penyelenggaraan, dan keluaran pendidikan.

Desentralisasi pendidikan bermula pada Tahun 2001, yang merupakan proses pemberian kewenangan kebijakan dibidang pendidikan dari Pemerintah Pusat untuk Pemerintah Daerah/Provinsi dan pelimpahan wewenang yang besar kepada lembaga sekolah dalam hal manajemen berbasis sekolah (MBS) salah satunya bidang manajemen pembiayaan pendidikan. Hal ini sejalan dengan hasil penelitilan Sumarsono, dkk, (2019) bahwa pelaksanaan manajemen berbasis sekolah yang perlu ditingkatkan salah satunya yaitu efisiensi dan efektivitas pembiayaan pendidikan.

Pemerintah Provinsi Kalimantan Selatan sebagai Pemerintah daerah memberikan penguatan berupa program Biaya Operasional Sekolah (BOS) dari APBD yang disebut BOSDA yang diperuntukkan membantu pemenuhan kekurangan dari dana BOS Pemerintah Pusat yang didapatkan sekolah selama ini. Dewan pendidikan dalam hal ini Dinas Pendidikan Provinsi memperjuangkan agar APBD bisa memberikan alokasi yang besar untuk BOSDA salah satunya untuk kesejahteraan para tenaga pendidikan yang memiliki peran besar dalam mencerdaskan juga untuk menambah kelancaran jalannya pendidikan dengan sarana dan prasarana yang mencukupi.

Penelitian menunjukkan bahwa Dewan pendidikan Provinsi Kalimantan Selatan telah berperan namun belum secara optimal sehingga masyarakat tidak mengetahui dan mengerti akan keberadaan dewan pendidikan. Tidak adanya peraturan daerah mengenai alokasi anggaran untuk kontribusi peranan dewan pendidikan menyebabkan dewan Pendidikan tidak dapat bekerja dan berkegiatan secara optimal. Dewan Pendidikan menurut Keputusan Menteri Pendidikan Nasional Nomor 044/U/2002 sebagai lembaga yang dibentuk untuk mewadahi aspirasi masyarakat seharusnya mampu mengoptimalkan peran dan fungsinya dalam meninggikan kualitas mutu pendidikan, pemerataan pendidikan di segala lini, dan efisiensi pengelolaan pendidikan. Pemerintah perlu memperhatikan alokasi sumber dana yang jelas bagi Dewan Pendidikan dalam aturan yang dibuat. Pekerjaan Dewan Pendidikan tidak mungkin bisa terlaksana apabila tanpa adanya dukungan dana. Pemerintah Daerah hendaknya menjalin kerjasama antar stakeholder dalam rangka pengelolaan alokasi dana didasarkan pada program dan skala prioritas yang sama, terkait upaya pemenuhan kebutuhan dan peningkatan mutu pendidikan masyarakat setempat. Hubungan kerja antara Dewan Pendidikan dengan lembaga sekolah terkait juga perlu ditinjau ulang, mengingat hubungan yang terjalin bersifat tidak mengikat satu dengan yang lain.

\section{SIMPULAN}

Pelaksanaan Manajemen Pembiayaan Pendidikan di SMA Negeri Kota Banjarmasin pascadesentralisasi pendidikan dengan pendekatan evaluatif menggunakan Model CIPP menunjukkan bahwa nilai tertinggi terdapat pada variabel proses yaitu 5053 poin dan nilai terendah pada variabel konteks sebesar 4667 poin.

Evaluasi pelaksanaan Manajemen pembiayaan pendidikan di SMA Negeri Kota Banjarmasin pada variabel pelaksanaan anggaran pendidikan, pengalokasian anggaran dana pendidikan, penatausahaan keuangan pendidikan, pertanggungjawaban keuangan pendidikan, dan pengawasan keuangan pendidikan berjalan dengan Efektif/Baik, sedangkan pada variabel sistem penyusunan anggaran pendidikan berjalan Cukup Efektif. Secara umum Manajemen pembiayaan pendidikan berjalan secara Efektif/Baik dengan nilai sebesar $86,12 \%$.

Dewan Pendidikan Provinsi telah berperan dan ikut berkontribusi dalam penentuan kebijakan pelaksanaan manajemen pembiayaan pendidikan namun belum optimal, sehingga masyarakat kurang menyadari kehadirannya. 


\section{DAFTAR RUJUKAN}

Arikunto, Suharsimi. (2014). Prosedur Penelitian: Suatu Pendekatan Praktik. Jakarta: Rineka Cipta.

Chairuwidha, Siti. (2019). Pengaruh Manajemen Pembiayaan Pendidikan terhadap Mutu Lulusan Kelas IX di SMP IT Ar Ridwan (Issues 24-Sep-2019) [UIN Syarif Hidayatullah Jakarta]. Skripsi.

http://repository.uinjkt.ac.id/dspace/handle/123456789/47752

Fatimah, Sri Witurachmi, dan Sohidin. (2008). Efektivitas Pengelolaan Dana Pendidikan Dalam Rangka Penerapan Mnajemen Berbasis Sekolah. Majalah Ilmiah Pengetahuan Sosial Vol.7 No 2 September 2008, Universitas Sebelas Maret | p-ISSN 1412-4475

https://www.neliti.com/publications/220547/efektivitas-pengelolaan-dana-pendidikan-dalam-rangka-penerapanmanajemen-berbasi\#cite

Herawati, Endang Sri Budi., Suryadi, Jumira Warlizasusi, dan Rusi Rusmiati Aliyyah. (2020). Kinerja Dewan Pendidikan Dalam Meningkatkan Mutu Pendidikan. TADBIR : Jurnal Studi Manajemen Pendidikan vol. 4, no. 1, Mei 2020 IAIN Curup - Bengkulu | p-ISSN 2580-3581; e-ISSN 2580-5037; https://doi.org/10.29240/ jsmp.v4i1.1435

http://journal.iaincurup.ac.id/index.php/JSMPI/article/view/1435

Matin. (2014). Manajemen Pembiayaan Pendidikan: Konsep dan Aplikasinya. Jakarta: Raja Grafindo Persada.

Mawardi, Agus Dian., \& Fadliah, Rina. (2020). Evaluasi Pelaksanaan Manajemen Berbasis Sekolah di Sekolah Dasar Negeri Kebun Bunga 6 Banjarmasin Timur Menggunakan Model CIPP. LENTERA: Jurnal Ilmiah Kependidikan, 15(1), 1-10.

https://jurnal.stkipbjm.ac.id/index.php/jpl/article/view/998

Mulyono. (2016). Konsep Pembiayaan Pendidikan. Yogyakarta: Ar-Ruzz Media

Peraturan Daerah Provinsi Kalimantan Selatan No.03 tahun 2010 tentang Pendidikan. https://peraturan.bpk.go.id/ Home/Details/39839/perda-prov-kalimantan-selatan-no-3-tahun-2010

Peraturan Daerah Provinsi Kalimantan Selatan No.03 tahun 2017 tentang Pendidikan. https://peraturan.bpk.go.id/ Home/Details/50596/perda-prov-kalimantan-selatan-no-3-tahun-2017

Putera, Ferdi Widi. (2013). Pembiayaan Pendidikan: Suatu Kajian Teoritis. Jurnal Pendidikan Dan Kebudayaan, Vol 19 Nomor 4.

https://jurnaldikbud.kemdikbud.go.id/index.php/jpnk/article/view/310

Riduwan. (2010). Metode \& Teknik Menyusun Tesis. Bandung: ALFABETA.

Riduwan. (2014). Dasar-dasar Statistika. Bandung: Alfabeta Press.

Riduwan. (2015). Skala Pengukuran Variabel-variabel Penelitian. Bandung: Alfabeta

Sugiyono. (2016). Metode Penelitian Kuantitatif, Kualitatif, dan R\&D.Bandung: Alfabeta.

Sumarsono, R. B., Triwiyanto, T., Kusumaningrum, D. E. \& Gunawan, I. 2019. Opportunities for the Implementation of School-Based Management in the Eastern Area of Indonesia. International Journal of Innovation, Creativity and Change. Volume 5, Issue 4, Special Edition: ICET Malang City, 2019. www.ijicc.net

Toifur. (2011). Peningkatan Kualitas Pendidikan Melalui Desentralisasi Pendidikan, Jurnal Insania Volume 16 No.2, 219-233

http://ejournal.iainpurwokerto.ac.id/index.php/insania/article/view/1589

Usman, Husaini. (2014). Manajemen: Teori, Praktik, dan Riset Pendidikan (Edisi 4, Cetakan Ke-2). Jakarta: Bumi Aksara. 